\title{
JV THE ROLE OF SUSTAINABLE DEVELOPMENT AND ITS CONCEPTS WITHIN RESIDENTIAL ARCHITECTURE
}

\author{
Saeid Yasinian \\ Department of Architecture, Hamedan branch, Islamic Azad University, Hamedan, Iran \\ syasinian@gmail.com
}

\begin{abstract}
Through development of urban communities, it is more vital to create residential areas. Quality of construction and architecture of residential areas has an important role in sustainable development of cities. There are many factors should be considered in development of construction of residential areas, some factors such as optimal use of constructible spaces and increase in construction speed. The concept of sustainable urban development has been one of the most important issues of urban problems that are considered as a development based on real needs and rational decisions considering different economic, social and environmental factors. Sustainable development is the confluence of society, economy and environment as well as an organizing principle for life of people. This assumption would prepare a great future for human communities without destroying sustainability of natural and environmental systems. This descriptive study has been conducted to assess the role of sustainable development and its concepts within residential architecture.
\end{abstract}

Keywords: sustainable development, residential architecture, habitability

\section{INTRODUCTION}

The sustainable development is based on environment, economy, and society and this system will lose its equilibrium if one of the mentioned bases is removed. Of course, sustainable development of environmental issues has a special priority in majority of evaluation systems and evaluation of economic and social aspects of sustainability seem complicated. On the other hand, environmental issues have considerably influenced on relevant strategies due to instant global warming. Therefore, common environment rules, ranking systems and construction regulations have assessed energy consumption and establishment of new technologies more than economic and social aspects. Although principles of sustainable development are similar throughout the world, but it would be essential to have a great understanding of sustainable buildings and sustainable development through specific approaches in accordance with different environmental conditions. A clear definition of sustainability is required in order to define sustainable evaluation system. To define determining rules of efficient and comprehensive sustainable development, ranking systems have been several times revised and developed in order to have more aspects of sustainability.

The issue of sustainable development has been one of the most important and common issues at international level. Environmentalist organizations of the world and Union Organization are important institutions involved in this issue. The serious discussion in this case was started after crisis and its culmination led to United Nations Conference on sustainable development known as "Earth Summit" in Rio de Janeiro in 1992 that was later called "Rio Summit" in which, a resolution was issued to propose some strategies for sustainable development of countries so that they were supposed to follow the resolution. 10 years later, another conference was held in Johannesburg, South Africa between ministers of countries and environmental experts in 2002 emphasizing on enactments of Rio Conference and implementation of these decisions at global level.

\section{SUSTAINABLE ARCHITECTURE}

According to OECD plan (Organization of Economic Cooperation and Development), sustainable buildings are those buildings with minimum destructing effects on surrounding constructed (artificial) and natural areas as well as around region and their total field. Sustainable buildings consider the total 
life cycle of building, high-quality environment, optimal functioning and future (Zandieh et al, 2010. Pp. 5-6). One of the most important goals of sustainability is compensation for lost advantages through industrialization and apparent development leading to preservation of ecosystems and optimal use of natural talents to keep them for future generations and preventing them from destruction beside promotion of life quality of human. Another goal of sustainability is consideration of natural environments such as greenhouse effect and destruction of the ozone layer (Sattari et al, 2012, P. 5).

Building construction is second great industry of the world after agriculture. The pollution originated from cooling systems of buildings and constructing materials would be more than pollution of cars and rapidly consume nonrenewable sources.

Sustainable architecture cannot be considered as a style in architecture but this is a smart attitude toward design emphasizing on reduced natural energy consumption and optimal use of natural energy sources.

Sustainable development not only tries to sustain the physic of buildings but also its final aim is creation of sustainability in Earth.

International Research Organization of Building Research (CBI) has introduced four goals of sustainable architecture as follows:

- $\quad$ reducing consumption of primary sources

- $\quad$ reuse of resources

- $\quad$ use of renewable resources

- environmental protection

\section{THE CONCEPT OF DEVELOPMENT AND SUSTAINABLE DEVELOPMENT}

Development can be defined as the evolution of life level and reach to an ideal condition in terms of economic, social, and cultural scopes along with realization of some concepts such as freedom, justice, social dynamic, human development, and economic, social, and cultural development. Development is also a discovery method to access to an evolutionary movement balancing social, economic, and cultural phenomena through preparing conditions for social and economic dynamic as well as realizing social justice (Zahedi Asl, 2002). Accordingly, the main goal of development is providing benefit for human such as improvement of life quality, increase in income and development of employment and public welfare (Keith Griffin, 1996). Concept of sustainable development was first proposed in Brundtland Report. According to this report, sustainable development is a development the meet the needs of present generation without threatening ability of future generations to meet their needs (Shiee, 1999).

Sustainable development is a development that considers the present needs of human in accordance with ability of future generations to meet their needs. Sustainable development has been considered since 70 decade through scientific communities of the world because of logical growth of a new awareness toward global issues in environment and development scopes so that this development has been affected by some factors including environmental movements of $60 \mathrm{~s}$ decade, published books such as "growth limitations" and the first conference of United nations on environment and development held in Stockholm in 1972. Sustainable development is a qualitative development that considers qualities of life with the aim of maximizing level of quality life or future generations (Mahmoodi, nd).

Sustainable development is a development continuously done in order to meet the human needs and improve life quality. Sustainable society is a community living through relevant constant limitations to environment. Such society is not empty of growth, but is a society that identifies growth barriers and considers substitution strategies to achieve growth (Balan, nd).

Sustainable development includes deep concepts within three scopes of environmental sustainability, economic sustainability, and social sustainability. The idea of environmental sustainability suggests 
land protection for future generation with this definition that human activity is environmentally sustainable if it is done without reducing natural resources or natural environment.

Environmental sustainability in work of architects is determined with following goals:

- $\quad$ minimum consumption of energy sources

- $\quad$ use of renewable materials

- $\quad$ preserving and supplying energy and complete recycling of energy without pollution

The principle of sustainable design is based on this point that building is a small component of surrounding environment that should be act as a part of ecosystem through life cycle.

\section{SUSTAINABLE DEVELOPMENT AND EMPOWERMENT}

Empowerment should be the final goal of every project of society development. Contrary to development interpreted as a flow of sources of outside into the society, empowerment would make all society members participate to change the world by themselves from inside to outside (Adhiutama\& Dowaki, 2013, P. 1008). Sustainable development aims to create a considerable change in relationship between human and nature while proposed solutions by sustainable development in field of architecture are modern and automatic solutions. According to majority of relevant studies to sustainable architecture and sustainable development, modern attitude of Bacon seems prior in them. He believed "world is created for human not human for world", it means benefiting from nature under the conditions that it is not destroyed and is usable for human (Gorji Mahlabani, 1967, P. 69). The mentioned issue is not just related to nature and environment but also it includes society.

Spear and Hogi concluded that organizing of society is the best way to empowerment; they also declared that there is a strong relationship between local communities and environment. As every foreigner (alien) should know mental and physiologic situation of society in order to reach social power, all methods should be considered in development as they are done in empowerment project (Adhiutama\& Dowaki, 2013, P, 1009). Systematic attitude to this issue is equal to organization of society to achieve major goals and creation of a socialist attitude that is extremist attitude. According to positive attitude toward this issue, empowerment of society without creation of infrastructures is a pointless issue. Access to mental and physiologic situation of a society is only to dominate on the identity and culture of society and overpower of fake identity to considered developing society. There are some debates in every century with the aim of leading developing societies to modern thought and idea in order to dominate social power and identity of a country. According to paper of Adaotama, the gradual conquest of modern thoughts in developing communities can be seen, these communities believe in schematic development of West as the only way of development. Obviously, modern thinking under the title of sustainable development is overcoming on developing countries. Sustainable development structurally meets the needs of present and future generations if there is a comprehensive attitude toward the issue.

Dr. Shariati has stated about the relationship between people in traditional and modern societies "relationships between people of a modern society are rational relationships based on necessities while the relationships between people of a traditional society are based on instinct, mental and moral sense" (Shariati, 2005, P. 204). Accordingly, Shariati considers the modern reason prior to conventional wisdom and defines it as an instinct wisdom so that there is different between this attitude and traditionalists. However, modern rationalism is not able to solve mental crises. Sustainable development is a development meeting present needs without threatening ability of future generations. The purpose of modern human (secular human) is benefiting from this life. Francis Bacon (1525, P. 68) was looking for a new science in order to enable human to dominant the nature through power. Modern human would use wisdom to achieve success through efforts (Hojjat, 1969, P. $57)$.

Non-developed societies should be developed by developed societies in order to achieve sustainable development. Empowerment means making changes in developing communities in order to lead them to desired way by themselves. Appropriate technology should be implemented as a booster through 
several steps within changing and evolution process. The mentioned steps should be included in three main chains of empowerment project in order to make sure about growth of effects of technology implementation (Adhiutama \& Dowaki, 2013, P. 1010).

Sustainability term is usually known as the final solution of development. However, the result is reverse. It is determined that sustainable development is imposed to rural community by foreigners' interference. According to some African samples, sustainable development would bring dependence to foreigners and aliens for members of the society (Adhiutama \& Dowaki, 2013, P. 1011).

\section{INDICATORS OF SUSTAINABLE URBAN DEVELOPMENT}

World Commission on Environment and has introduced following principles as necessary features of a sustainable city.

1. Increase in social and economic opportunities to support urban residents

2. Decrease in energy share in urban growth

3. Optimal use of water, land and other sources required for urban growth

4. Minimization of waste and sewage and maximizing recycled wastes

5. Creating management systems with sufficient power and efficiency to achieve environmental, social, and economic goals

6. Applying technologies of city to access to sustainable development

7. Reinforcement of different urban areas to achieve economic, social and environmental goals and respond to threats created by natural or human factors as well as dealing with unexpected disorders in urban system; in this relation, a sustainable city is a city in which, social justice is realized through a high-quality life (Azizi, 2001, P. 22). It is necessary to assess some relevant indicators to sustainability of cities. These factors are as follows (Gharakhloo \& Hosseini, 2006, Pp. 164-174):

1. Population: the main factor of urban sustainability is population and its economic, social, environmental, and managerial effects on cities even biosphere. Hence, it would be required to consider population as the most important factor in urban sustainability. Assessment of population number, growth rate of population, immigration and its effect on demographic structure of city can be effective to achieve urban sustainability.

2. Economic situation: cities as open systems in globalization, global village and communication era should expand their communications at regional, national and international levels in order to be remained. It is necessary for cities consider their development strategies and economic infrastructures through a method in order to keep economic sustainability of the city, use their potentials and situations within different local, national and international dimensions and develop a higher quality of life for residents. The main purpose of a city in a global competition environment should be based on two points: maximum use of economic capabilities and potentials and creation of various economic activities in city in order to deal with unexpected disorders and fluctuations of world environment.

3. Climate change: according to development of urbanism in current years, it would be required to recognize changes in world climate due to urbanism in order to access to urban sustainability or global sustainability. In general, international environmental treaties have created a key strategy in which, different nations and countries come to an agreement about environmental problems to reduce or solve such problems.

4. Air pollution: cities are the main polluters of environment weather at a local, national and international scale; hence, it would be vital to recognize polluting and intensifying factors in urban environment and reduce them in order to access to urban sustainability. 
5. Quality of natural water: there should be some important factors in a city to be considered as a sustainable city. These factors include preparation of healthy water for residents, preventing from a disorder in biologic quality of surface and underground water resources around cities, preventing from pollution or disruption of water supplies in other cities and biologic areas around cities through the excessive use or pollution of biologic sources of these cities.

6. Open society: not only occupy cities different hierarchical levels, but also are considered as a part of a network. There are different flows of information, capital, labor force, products and services within this global network of cities. Common perception of cities about their situation as well and interactions between them in this network would guarantee sustainability of the network. The mutual interaction between cities within different economic, environmental, social, and cultural scopes has made cities to collaborate with each other through global urbanism network in order to be remained.

7. Coherent and integrated planning: complexity of cities beside diversity of subjects and involved organizations in study of urban issues and problems $f$ have made planners and policy-makers to select an integrated plan in order to have appropriate planning and make balance between different priorities, preferences and needs of interferers. This point has been more considered today mentioning that integration of executive rules and regulations among responsible institutions and organizations is an effective factor in an efficient urban planning. Creation and use of a set of organized and integrated rules and regulations is a method creating effective yield through coordinated collaborations so that the feedback will be considered as a basic strategy for cities to strengthen communications, correlation and coherence in society.

8. Ability and potential of innovation: a city should be able to innovate in order to have capacity and potential of adaptability and compatibility. Without appropriate innovation, a city is not able to adapt with crises and disorders rapidly. Evolution ability inside the global competitive market would create a base for a compatible urban pattern. A city should have a strategic planning and policies and plans should allow the city to determine its future.

9. Relevant potential and capacity to regional infrastructure: infrastructural potentials are facilities and equipment such as transportation and communication systems (rile, air, road, sea) making relation between city and the rest of the world. The mentioned infrastructures should be developed to make it possible for city participating in global economy. Speed is a basic and important factor of participation in global business so that the city will be in improper economic, social, and cultural situation if people, information and products are not able to move between places and areas rapidly. Some options can be considered to evaluate this index, these options include capacity of import and export gates of city to import and export products and services such as capacity of airports in terms of transportation of cargo and passengers, capacity of passenger and cargo terminals and quality of its facilities and equipment, the quality of telecommunications in the city such as the number of telephone and Internet subscribers, etc.

10. Social capital: some indices can be used to recognize the capacity of social capital of the city. These indices include number and type of Organizations, non-governmental organizations and local communities, per capita of them and length of membership, community groups and their per capita, level of awareness and understanding of people toward social structures. In other words, social capital is determined through membership level of people in groups and networks.

11. Education and training: there is a relationship between social movement and change and ability of educational system to teach life skills and jobs to people. When economy of cities is getting more and more global through various service sectors, jobs will get more and more specialized so that the awareness of relationship with the world will rapidly developed.

12. Security: security is one of the most important needs of human that meet some needs such as sense of belonging, respect and self-actualization as well as physiologic needs. A sustainable city needs a sustainable, safe, and secure environment and area for its residents. 


\section{CONCLUSION}

Sustainable development is a movement based on human and environment considering development of economic facilities in accordance with environmental considerations and social justice. Sustainable development was considered due to the problems originated from only economic development after world war when there was an irregular development causing social gaps and environmental problems with less attention toward environmental and social aspect compared to economic aspect.

All relevant concepts to sustainable development were considered through development of urbanism in human life and sustainable urban development is a result of new perspective toward social, spatial and environmental justice in the city. Cities will contain $75 \%$ of the whole population of the world by 2020 while they have $2 \%$ of urban space. Therefore, this strange and unprecedented density of population and public need to attract basic resources would lead to abnormal exploitation from local and neighborhood resources. The effects of this development are along with unprecedented wastes of cities leading to pollution, diseases, and new types of suburban life, but sustainable urban development as a part of sustainable development is based on reasonable use of natural sources including environmental, economic and social considerations.

\section{REFERENCES}

Adhiutama,Akbar., Kiyoshi Dowaki., (2013), Community empowerment through appropriate technology: sustaining the sustainable development. Procedia Environmental Sciences 17, 1007 1016. Available online at www.sciencedirect.com

Azizi, M. M., (2001), sustainable urban development, analysis from a global perspective, Faculty of Architecture, University of Shaheed Beheshti, the eleventh year, Issue 33, Autumn and Winter

Balan, A., the concepts of sustainable development, Journal of Jihad, eighteenth year, Issue 91-912

Gharakhloo, M., Hosseini, S. H., (2006), Indicators of Sustainable Urban Development, Journal of Geography and Regional Development, Issue 8

Gorji, Mahlabani, Y., (1967), sustainable architecture and criticizing it as the environmental scope, Journal of Association of Architecture and Urbanism, Iran, Issue 1

Hojjat, I., (1967), Human identity, identity processor human, Journal of Beautiful Arts, Issue 24

Keith G., Mac Kennelly, T., (1996), realization of human development strategies, Gholamreza Khajeh Pour Trans, Social Security Research Institute, Tehran

Mahmoodi, M., sustainable design principles in line with the objectives of sustainable development www.IranCivilCenter.com

Sattari Sarbangholi, H., Nadri Benam, N., (2012), comparative study of indicators of sustainable architecture in the contemporary era with the teachings of the Holy Quran, Journal of Literature and Religious Art, Issue 4, Pp. 73-103

Shariati, A., (2005), Features of the new century (Collected Works of 31), Tehran, Chap Pakhsh Pub, Seventh Edition

Shiee, I., (1999), the city and region in Iran, first edition, Iran University of Science and Technology, Tehran

Zahedi Asl, M., (2002), basics of social welfare, Tehran, Allameh Tabatabai University Press

Zandie, M., Parvarinejad, S., (2010), Sustainable development and its concepts in residential architectural of Iran, Journal of Housing and Rural Environment, Issue 130, Pp. 2-12 